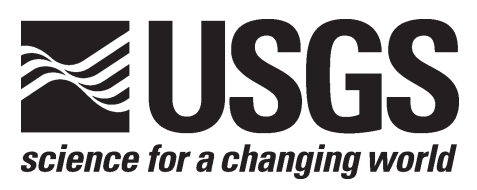

\title{
Applying Probabilistic Well-Performance Parameters to Assessments of Shale-Gas Resources
}

By Ronald R. Charpentier and Troy Cook

Open-File Report 2010-1151 


\section{U.S. Department of the Interior \\ KEN SALAZAR, Secretary}

\section{U.S. Geological Survey \\ Marcia K. McNutt, Director}

U.S. Geological Survey, Reston, Virginia 2010

For product and ordering information:

World Wide Web: http://www.usgs.gov/pubprod

Telephone: 1-888-ASK-USGS

For more information on the USGS-the Federal source for science about the Earth,

its natural and living resources, natural hazards, and the environment:

World Wide Web: http://www.usgs.gov

Telephone: 1-888-ASK-USGS

Suggested citation:

Charpentier, R.R., and Cook, Troy, 2010, Applying probabilistic well-performance parameters to assessments of shale-gas resources: U.S. Geological Survey Open-File Report 2010-1151, 18 p.

Any use of trade, product, or firm names is for descriptive purposes only and does not imply endorsement by the U.S. Government.

Although this report is in the public domain, permission must be secured from the individual copyright owners to reproduce any copyrighted material contained within this report. 


\title{
Applying Probabilistic Well-Performance Parameters to Assessments of Shale-Gas Resources
}

\author{
Ronald R. Charpentier \\ Troy Cook \\ U.S. Geological Survey
}

\section{‡USGS}

This presentation was first given at the American Association of Petroleum Geologists Annual Convention and Exhibition in New Orleans, Louisiana, on April 12, 2010. 


\section{USGS Assessments Before 1995}

- In-place estimate plus estimate of recovery factor

- Volumetric calculations of rock volumes and resource densities

- In pore space

- Sorbed

- Recovery factors poorly known

\section{₹USGS}




\section{USGS Assessments \\ 1995 to Present}

- Well production data used to derive a distribution of estimated ultimate recoveries (EURs)

- Divide assessed area into cells

- Calculate numbers of untested cells

- Apply EURs to cells

\section{\#USGS}




\section{Methodology Needs}

- Digest larger volumes of production data

- Better include geologic understanding of spatial and temporal trends

- Apply analog information to hypothetical or very immature assessment units

\section{\#USGS}




\section{Present Calculation Method}

- Present USGS method calculates as if you were sampling from the EUR distribution thousands of times independently

- Calculates as if mean EUR were known exactly

- Underestimates uncertainty

\section{₹USGS}




\section{Improved USGS Methodology}

- Directly estimates uncertainty of EUR

- Affected by temporal and spatial trends

- Depends on geology, not just data

- Based on wells, not cells

- Assesses sweet spots and nonsweet spots

\section{\#USGS}




\section{Temporal Trends}

- Historical success ratios and EUR distributions may not be appropriate for future drilling

- Look at temporal changes in EUR distribution

- Changes in technological practice

- Changes related to geology

\section{\#USGS}




\section{First Full Month of Production}

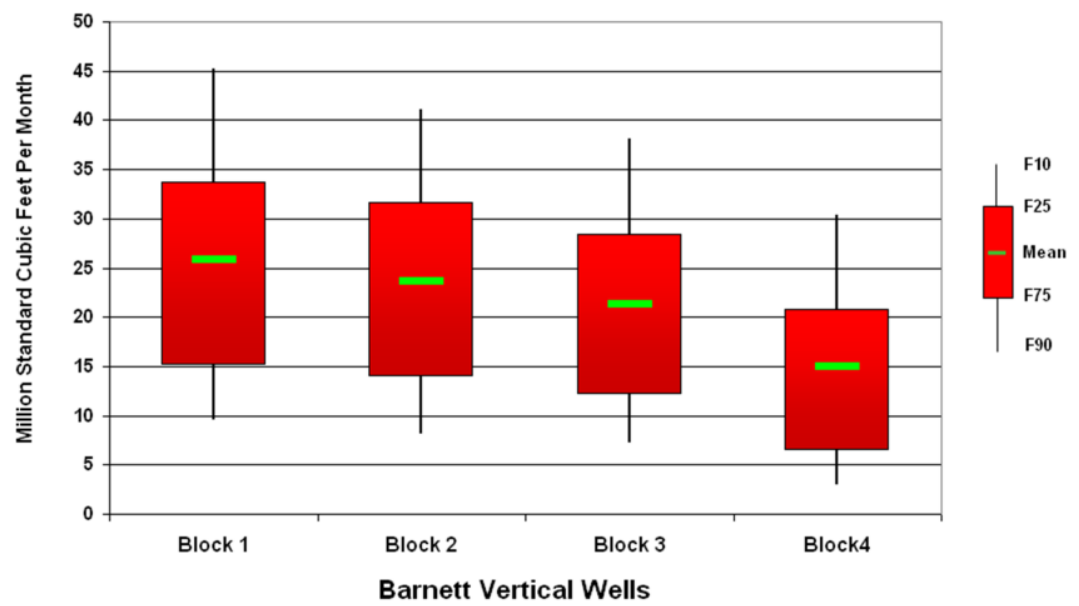

\section{‡USGS}

This diagram shows distribution of production for four groups of vertical Barnett Shale wells of roughly equal size, with group 1 containing the earliest wells and group 4 the most recent. The data show a decrease in first full month well production over time. 


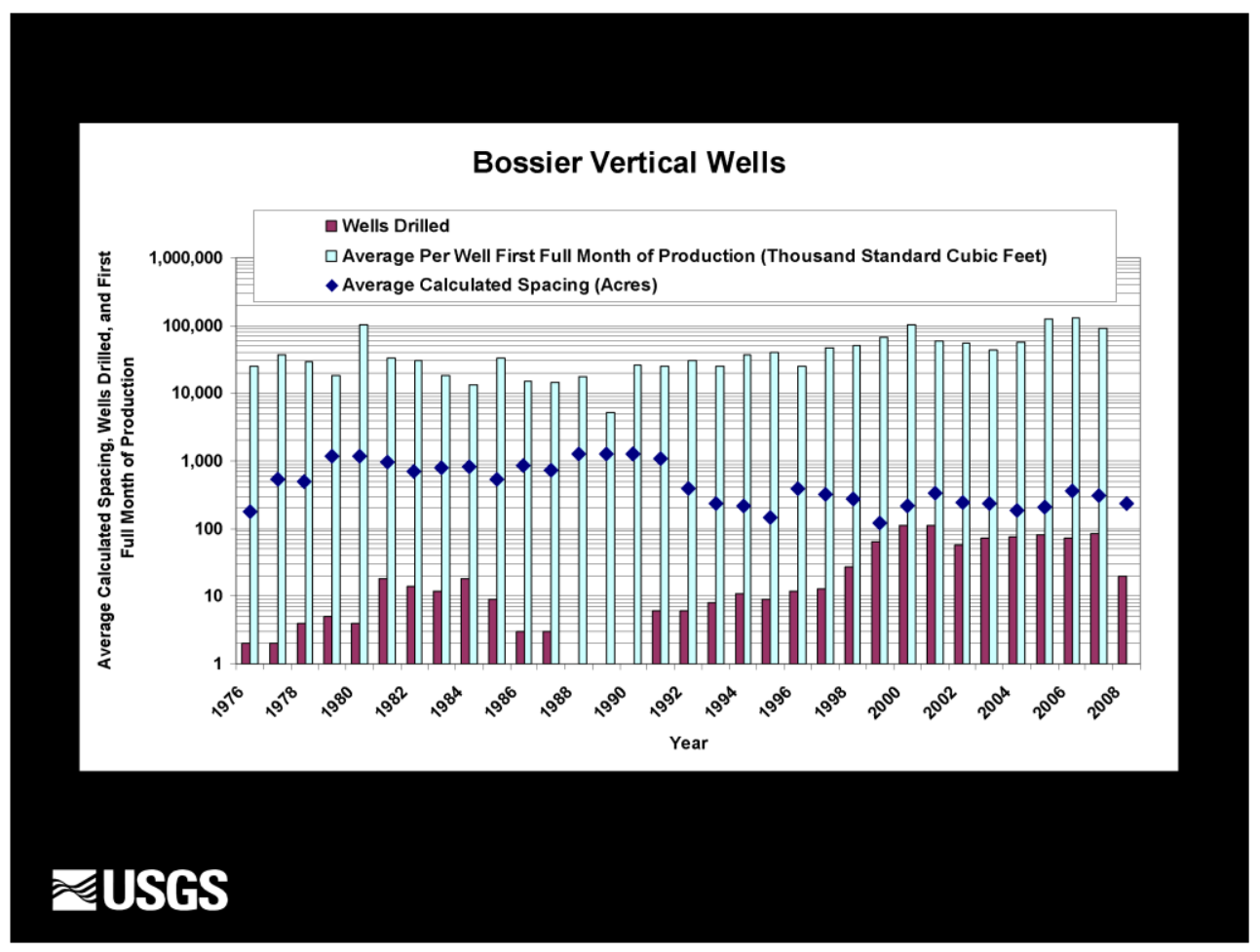

This figure compares trends in Bossier Formation well characteristics over time. Around 1990, there was an increase in drilling accompanied by a decrease in average well spacing and an increase in average first full month production. Data for 2008 are incomplete. 


\section{Spatial Trends}

- Look at spatial changes in EUR distribution

- Define sweet spots

- Compare to known geology

- Thickness

- Total organic carbon (TOC)

- Thermal maturity

\section{‡USGS}




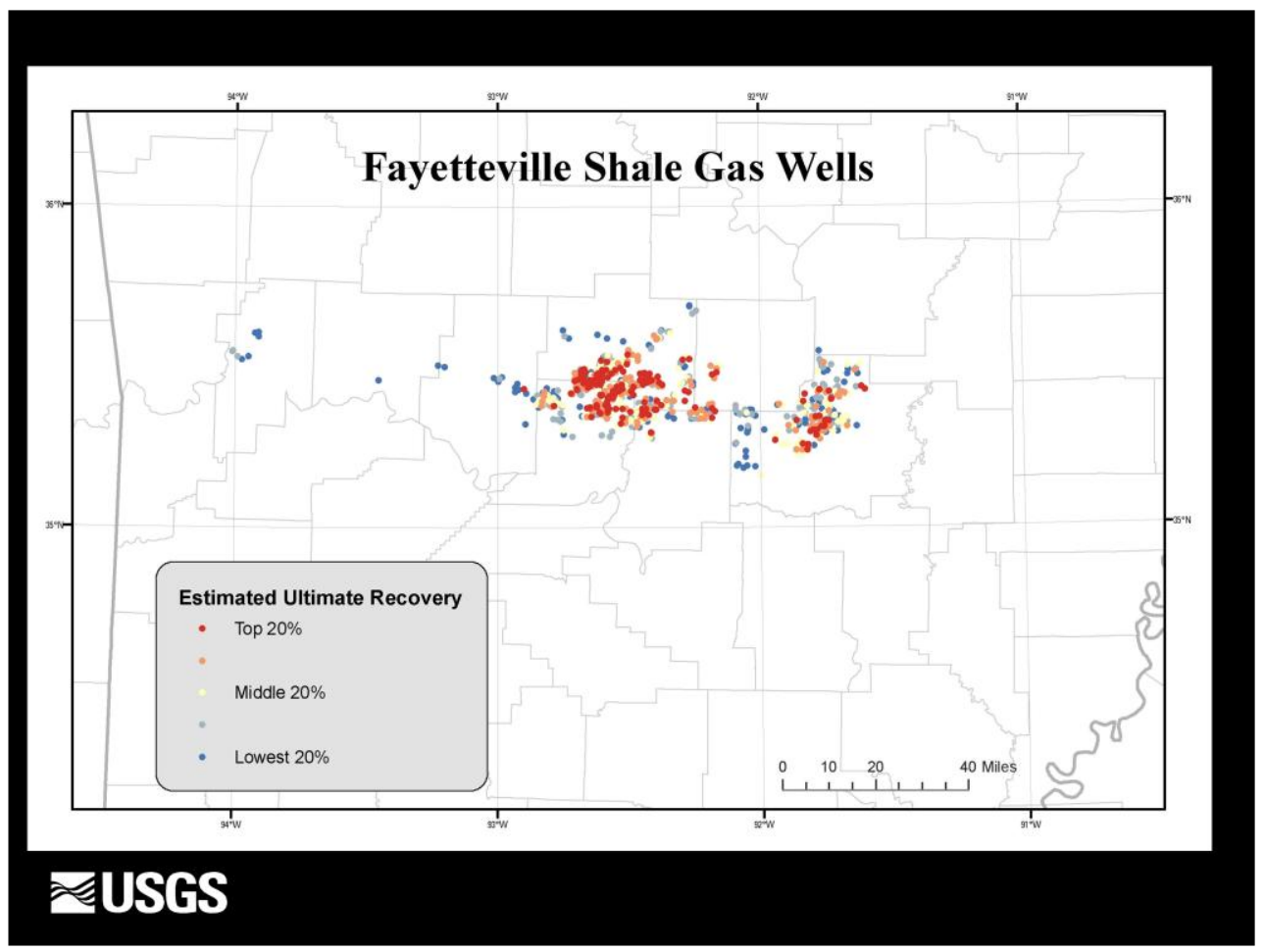

This map shows estimated ultimate recoveries (EURs) of Fayetteville Shale gas wells and how they cluster into sweet spots. 


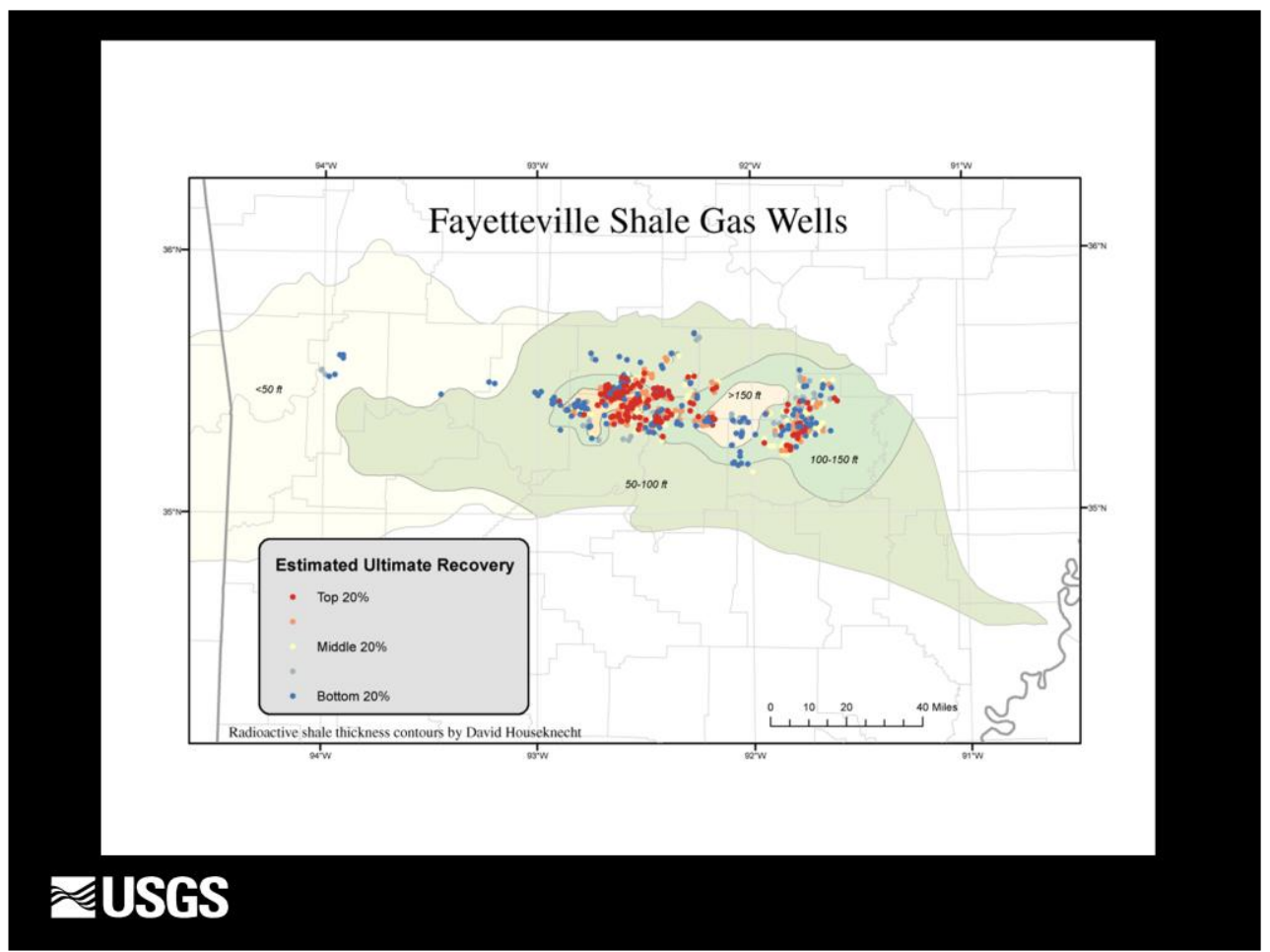

This map compares the well EURs of the previous map to the thickness of radioactive shale (as contoured by David Houseknecht, USGS). Note the moderate level of correlation between EUR and shale thickness. 


\section{Risk}

- Divide the assessment unit into a quantitatively assessed area and an area that has no significant resource potential

- How much of the shale is a self-sourced reservoir?

$->2 \%$ total organic carbon, and

- Adequate maturity (thermal or biogenic)

\section{\#USGS}




\section{Quantitatively Assessed Area}

- Option to divide the assessment area geologically into sweet spots and nonsweet spots

- Not necessarily mappable at this time

- Each part has its own success ratio and its own EUR distribution

\section{‡USGS}




\section{Application to Data-Poor Environment}

- Risk becomes much more important

- Uncertainty of mean EUR is large source of overall uncertainty

- Analog datasets

\section{\#USGS}




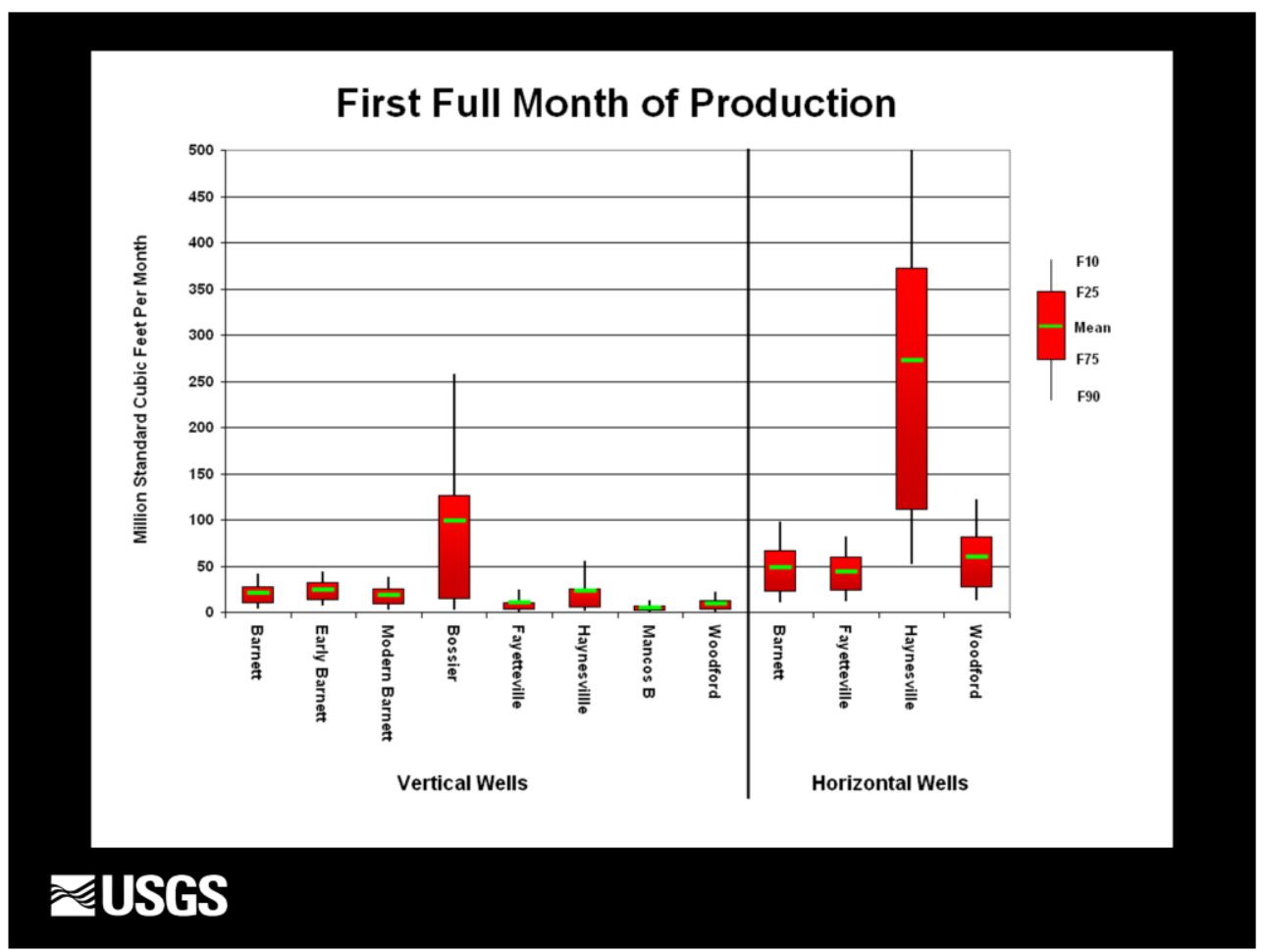

Comparison of several groups of shale-gas wells that could be used as analogs for assessments of data-poor areas. The box-and-whisker plots summarize the distributions of the first full month of production, which is commonly the highest monthly rate of production. Note the contrast between distributions of vertical and horizontal well productivities within the same formation. F90 denotes a 90 percent chance of at least the amount tabulated. Other fractiles are defined similarly. 


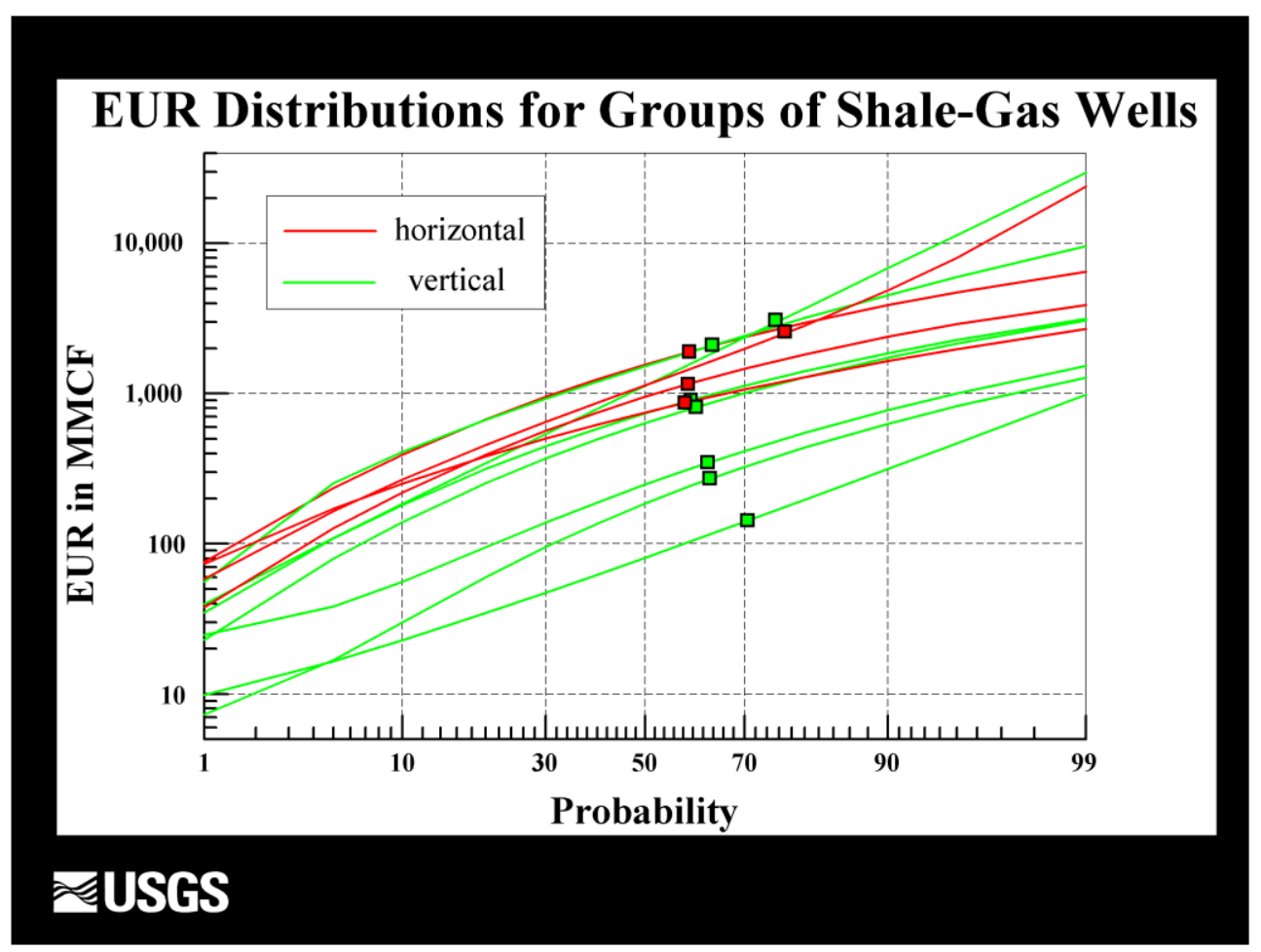

This is another way of comparing EUR distributions for analog groups of shale-gas wells. Squares represent the mean of each distribution. Note the large variation among groups. For example, the means for vertical well groups differ by greater than an orderof-magnitude. $\mathrm{MMCF}=$ millions of cubic feet. 


\title{
For more information go to:
}

\author{
http://energy.cr.usgs.gov/oilgas/ \\ noga/methodology.html
}

\section{‡USGS}

